\title{
Jurnal Ilmiah Administrasi Publik (JIAP)
}

\section{Pelayanan Penerbitan Sertifikat Kepemilikan Tanah (Studi pada Kantor Pertanahan Nasional Kabupaten Bondowoso)}

\author{
Sela Febby Wardaty ${ }^{a^{*}}$, Sumartono $^{\mathrm{b}}$, Endah Setyowati ${ }^{\mathrm{c}}$ \\ ${ }^{a}$ Universitas Brawijaya, Malang, Jawa Timur, Indonesia
}

\section{INFORMASI ARTIKEL}

\section{Article history:}

Dikirim tanggal: 13 September 2019

Revisi pertama tanggal: 20 September 2019

Diterima tanggal: 07 Juli 2020

Tersedia online tanggal: 21 Agustus 2020

Keywords: public service, service quality, land

\section{ABSTRACT}

In the case of the development of public services, it is not merely an administrative problem or merely fulfilling the physical needs of service quality and customer satisfaction, especially considering that both of them have a major influence on the sustainability and development of an organization's mission. Such services must be accessible to the community without exception, regardless of socioeconomic status, race, ethnicity, religion and other subjective characteristics. As a service provider for citizens, the government is required to further optimize and be able and able to fulfill all its responsibilities to the community, both in terms of quality and quantity of service. Problems that occur in the Bondowoso District National Land Office are problems of poor service quality, good service quality will produce good output for the community and for the Land Office itself. The services available at the Land Office are a bit complicated and difficult for the public. The service of land certificates will make people's lives better with clear legal certainty.

\section{INTISARI}

Dalam hal perkembangan pelayanan publik bukan semata-mata persoalan administratif belaka atau sekedar pemenuhan kebutuhan fisik, kualitas pelayanan dan kepuasan pelanggan sangat diutamakan menngingat keduanya mempunyai pengaruh besar terhadap keberlangsungan dan pengembangan misi suatu organisasi. Pelayanan seperti ini harus dapat diakses oleh masyarakat tanpa terkecuali, tanpa melihat status sosial ekonomi, ras, etnis, agama, dan ciri-ciri subjektif lainnya. Sebagai penyedia jasa bagi warga negara, pemerintah dituntut untuk semakin mengoptimalkan dan mampu memenuhi segala tanggung jawabnya terhadap masyarakat, baik dari segi kualitas maupun dari segi kuantitas pelayanan. Permasalahan yang terjadi di Kantor Pertanahan Nasional Kabupaten Bondowoso merupakan permasalahan kualitas pelayanan yang kurang baik. Kualitas pelyanan yang baik akan mengeluarkan output yang baik bagi masyarakat serta bagi Kantor Pertanahan itu sendiri. Pelayanan yang terdapat di kantor pertanahan sedikit berbelit, sehingga menyulitkan masyarakat. Pelayanan sertifikat tanah akan menjadikan kehidupan masyarakat yang lebih baik dengan adanya kepastian hukum yang jelas. 


\section{Pendahuluan}

Saat ini pelayanan publik dapat dijadikan indikator dalam menentukan good governance, karena dalam pelayanan inilah pemerintah berhadapan langsung dengan masyarakat. Baik dan buruknya citra pelayanan akan mempengaruhi kepercayaan masyarakat kepada pemerintah. Pelayanan harus sesuai dengan asas, prinsip, dan standar yang telah ditentukan. Berdasarkaran UU No. 25 Tahun 2009, pelayanan publik yang diberikan oleh penyelenggara didasarkan atas kepentingan umum, untuk itu partisipasi masyarakat dalam pelayanan sangat penting. Dengan adanya partisipasi dari masyarakat, akan mudah bagi penyelenggara layanan untuk memahami kebutuhan dan harapan masyarakat. Pengawasan terhadap jalannya pelayanan harus dilakukan untuk menjaga kualitas layanan. Dalam pemberian layanan tidak diperbolehkan membeda-bedakan masyarakat. Semua lapisan masyarakat mempunyai hak dan kewajiban yang sama untuk mendapatkan pelayanan. Penyelenggara layanan harus melakukan pengawasan internal untuk menjaga kualitas layanan kepada masyarakat. Diperlukan pelayanan publik yang profesional dibidangnya, bertanggungjawab, dan mampu melaksanakan standar dan prosedur yang sudah ada. Untuk itu diperlukan payung hukum, agar pelayanan berjalan dengan baik. Pelayanan juga harus dilakukan dengan murah, cepat, mudah dan terjangkau.

Sebagai institusi pelayanan publik, Kantor Pertanahan Kabupaten Bondowoso senantiasa berupaya meningkatkan kualitas pelayanan. Salah satu upaya yang ditempuh adalah dengan melakukan perubahan pola pelayanan kepada masyarakat, dari pelayanan manual menjadi pelayanan yang berbasis komputerisasi dengan tujuan tertib adminitrasi terkait kedisiplinan kerja. Pemerintah Kabupaten Bondowoso saat ini lebih berusaha untuk mengakses semua kepentingan masyarakat baik lokal, regional hingga nasional di segala sektor khususnya dalam sektor pelayanan publik untuk masyarakat. Salah satu upaya yang dilakukan oleh Pemerintah Kabupaten Bondowoso yaitu dengan pengembangan sarana dan prasarana pelayanan masyarakat yang nyaman, termasuk fisik bangunan. Kondisi fisik sebuah instansi memberikan dampak besar terhadap kinerja pegawai kantor yang berkaktivitas didalamnya dan kepuasan masyarakat yang membutuhkan pelayanan.

Kenyataan yang terjadi dilapangan saat ini menunjukkan bahwa Kantor Badan Pertanahan Nasional Kabupaten Bondowoso dapat dikatakan sebagai kantor pelayanan yang sudah tidak representatif. Hal ini terlihat dari segi kapasitas, aktivitas, dan kondisi fisik bangunan. Kantor Pertanahan Nasional Kabupaten Bondowoso melayani penerbitan sertifikat kepemilikan tanah dengan jumlah rata-rata pelayanan lebih dari 1000 pelayanan setiap tahunnya. Jumlah pelayanan yang tercatat pada
Tahun 2014 adalah 1161 pelayanan setiap tahun, sedangkan pada Tahun 2010 jumlah pelayanan yang tercatat adalah 1653 (mengalami peningkatan sebesar 9\%). Kondisi demikian yang menyebabkan kurangnya kapasitas ruang pelayanan dan ruang arsip. Pada saat ini kantor Badan Pertanahan Nasional Kabupaten Bondowoso memiliki tiga loket pelayanan dan 25 kursi diruang tunggu. Sedangkan berdasarkan hasil survey yang dilakukan jumlah rata-rata pengunjung di Kantor BPN setiap harinya saat ini berjumlah kurang lebih 50 orang dan dalam kurun waktu lima tahun mengalami peningkatan sebesar $18 \%$. Hal tersebut membuktikan kapasitas diruang pelayanan dan ruang tunggu masih kurang. Ruang arsip merupakan suatu ruang khusus untuk menyimpan dokumen-dokumen penting yang tidak boleh dimusnahkan. Ruang arsip yang ada saat ini memiliki luas kurang lebih $200 \mathrm{~m}^{2}$ dan sudah penuh, sehingga sangat dibutuhkan penambahan ruang untuk ruang arsip. Hal tersebut berdampak untuk memunculkan permasalahan baru terhadap fungsi ruang yang lainnya, salah satu yang terkena dampak adalah ruang kerja karyawan yang luasnya sedikit demi sedikit berkurang karena sebagian dari space digunakan untuk meletakkan dokumen-dokumen. Kondisi demikian juga mempengaruhi kinerja karyawan karena karyawan merasa space yang digunakan untuk beraktivitas/ bekerja menjadi berkurang dan terbatas.

Wujud nyata dari segala permasalahan pelayanan publik yang dapat dilihat pada pelayanan pembuatan sertifikat tanah di Kantor Pertanahan Kabupaten Bondowoso, dimana kantor ini memiliki kewenangan untuk melaksanakan pendaftaran tanah diseluruh wilayah Republik Indonesia. Akan tetapi dalam realitanya, pelaksanaan penerbitan sertifikat kepemilikan tanah di Kantor Pertanahan Kabupaten Bondowoso belum terlaksana dengan baik dikarenakan masih banyaknya masalah seperti bidang tanah yang baru di-sertifikat sekitar 36\% dari total 816.000 bidang tanah yang ada di Kabupaten Bondowoso. Dalam proses penerbitan sertifikat tanah seringkali terlambat dari waktu yang telah ditentutukan oleh pemerintah. Kemudian $85 \%$ dari pemohon layanan merupakan perantara yang sebagian besar adalah calo, selain itu masalah syarat dan prosedur pengurusan sertifikat tanah masih dirasa cukup sulit dan berbelit-belit.

Menurut Dwiyanto (2008, p. 145) menyatakan bahwa kualitas pelayanan publik harus memenuhi beberapa aspek, yaitu tangibles, realibility, responsiveness, assurance, dan empaty. Pada kenyataannya pelayanan publik di Indonesia banyak mendapat citra buruk dari masyarakat. Hal itu dapat ditunjukkan dengan kekecewaan masyarakat melalui pengaduan atau laporan menyangkut pelayanan publik kepada instansi terkait maupun lembaga negara yang mengawasi pelayanan publik di Indonesia. Buruknya 
pelayanan publik hampir terjadi disemua lembaga publik yang ada.

Berdasarkan latar belakang yang telah diuraikan diatas, penelitian ini dilakukan untuk menganalisis "Pelayanan Pernerbitan Sertifikat Kepemilikan Tanah di Kantor Pertanahan Nasional Kabupaten Bondowoso".

\section{Teori}

\subsection{Pelayanan Publik}

Pelayanan publik merupakan salah satu wujud dari fungsi aparatur negara sebagai abdi masyarakat dan abdi negara. Pelayanan publik oleh birokrasi publik diharapkan bisa untuk meningkatkan kesejahteraan masyarakat. Kondisi masyarakat saat ini telah berkembang dengan sangat dinamis, dilihat dari tingkat kehidupan masyarakat yang semakin baik, merupakan sebuah indikasi dari empowering yang dialami oleh masyarakat (Dwiyanto, 2005). Pelayanan publik merupakan produk birokrasi publik yang diterima oleh masyarakat secara luas. Adapun yang dimaksud pelayanan publik disini adalah segala bentuk kegiatan pelayanan yang dilaksanakan oleh instansi pemerintah (Dwiyanto, 2008). Lebih lanjut Dwiyanto (2012) mengatakan bahwa keluhan warga pengguna layanan seringkali muncul bukan hanya karena ketidakpastian waktu dan biaya tetapi juga cara pelayanan yang mereka terima seringkali melecehkan martabatnya sebagai warga negara.

Kualitas produk dan proses penyelenggara layanan publik dapat diamati, dirasakan, dan dinilai secara langsung oleh warga. Sinambela (2014, p. 6) menyatakan bahwa kualitas pelayanan dapat digunakan sebagai indikator dalam mengetahui kinerja organisasi. Kualitas pelayanan prima tercermin dari transparansi, akuntabilitas, kondisional, partisipatif, kesamaan hak, serta keseimbangan hak dan kewajiban.

Tjiptono (2000, p. 70) mengemukakan yang mendukung hal tersebut dimana terdapat lima dimensi yang harus diperhatikan dalam melihat suatu tolak ukur kualitas pelayanan publik, antara lain a) tangibel, b) reability, c) responsiveness, d) assurance, dan e) emphaty. Kualiatas pelayanan yang baik juga harus memenuhi asas-asas pelayanan publik pada UU nomor 25 Tahun 2009 tentang Pelayanan publik; yang meliputi kepentingan umum, kepastian hukum, kesamaan hak, keseimbangan hak dan kewajiban, keprofesionalan, partisipatif, persamaan perlakuan/ tidak diskriminatif, keterbukaan, akuntabilitas, fasilitas dan perlakuan khusus bagi kelompok rentan, ketepatan waktu, serta kecepatan, kemudahan, dan keterjangkauan.

\subsection{Srategi}

Strategi sering kali menggambarkan taktik atau rencana suatu program untuk mencapai suatu tujuan yang diinginkan. Hakikatnya strategi merupakan perencanaan (planning) dan manajemen (management) untuk mencapai suatu tujuan. Akan tetapi, untuk mencapai tujuan tersebut, strategi tidak sekedar berfungsi sebagai penunjuk arah, melainkan harus bisa menunjukkan bagaimana taktik operasionalnya.

Strategi yang mencakup penentuan tujuan yang dibuat oleh manajemen perusahaan yang diharapkan akan menjamin terpeliharanya keunggulan kompetitif perusahaan (Abdul Wahab, 2012, p. 25). Didalam strategi yang baik terdapat koordinasi tim kerja, memiliki tema, mengidentifikasi faktor pendukung yang sesuai dengan prinsip-prinsip pelaksanaan gagasan secara rasional, efisien dalam pendanaan, dan memiliki taktik untuk mencapai tujuan secara efektif.

Strategy refers to either the plan made or the action in effort to help an organization fulfiil its intended propose and strategy refers to propose the organization stives to achive these strategy posed by typical businesses can be very broad (vision and mission) or more focused (goals and objectives). (Miller et al., 1993).

Lynch (2006, p. 22) menyatakan bahwa "Some countries are committed to the view that public companies are these to provide a public service. Strategy is therefore directed toward achieving this aim". Sektor publik memiliki kompleksitas yang lebih tinggi dari sektor privat serta sektor publik memiliki resiko yang lebih tinggi untuk menghadapi masalah, ruang lingkup masalah yang lebih luas.

\subsection{Administrasi Pertanahan}

Administrasi Pertanahan menurut Murad (1997) adalah sebagai berikut:

Suatu usaha dan manajemen yang berkaitan dengan penyelenggaraan kebijaksanaan pemerintah di bidang pertanahan dengan mengerahkan sumber daya untuk mencapai tujuan sesuai dengan ketentuan Perundang-undangan yang berlaku.

Landasan hukum dalam UUD 1945 mengenai administrasi pertanahan terdapat dalam Bab XIV tentang kesejahteraan sosial, Pasal 33 ayat (3) yang berbunyi "Bumi dan air dan kekayaan alam yang terkandung di dalamnya dikuasai oleh negara dan dipergunakan untuk sebesar-besar kemakmuran rakyat".

Pertanahan, menurut Rusmadi (1997, p. 1) adalah sebagai berikut:

Suatu kebijaksanaan yang digariskan oleh pemerintah di dalam mengatur hubungan hukum antara tanah dengan orang sebagaimana yang ditetapkan oleh Undang-undang Dasar 1945 dan dijabarkan dalam Undang-undang Nomor 5 Tahun 1960 yang dikenal dengan Undang-undang Pokok Agraria (UUPA). 
Sertifikat kepemilikan merupakan salah satu produk dari Badan Pertanahan Nasional. Sertifikat memiliki fungsi yang sangat penting yaitu sebagai alat bukti yang kuat, memberikan kepercayaan terhadap kreditur, dan sebagai data perencanaan pembangunan bagi pemerintah (Sutedi, 2012, p. 58). Dalam peraturan pemerintah Nomor 24 Tahun 1997 tentang Pendaftran tanah; telah mengikat para pejabat Badan Pertanahan Nasional untuk menerbitkan sertifikat sebagai alat pembuktian yang kuat atas kepemilikan tanah.

Dalam memenuhi hal tersebut Badan Pertanahan Nasional harus memnuhi asas yang telah diatur atau ditetapkan dalam peraturan Pemerintah No. 24 Tahun 1997, yaitu sederhana, aman, terjangkau, mutakhir dan terbuka. Penerbitan sertifikat dapat dilakukan dengan pendaftaran tanah secara sporadis maupun secara sistematis.

\section{Metode Penelitian}

Adapun tahapan dalam penelitian ini antara lain sebagai berikut:

a) Melakukan identifikasi data secara lebih mendalam terhadap pelayanan penerbitan sertifikat kepemilikan tanah di Kantor Pertanahan Nasional Kabupaten Bondowoso;

b) Melakukan identifikasi aktor dan peranan keterlibatan didalam proses pelayanan penerbitan sertifikat kepemilikan tanah;

c) Menganalisis aturan-aturan yang berkaitan dengan proses pelayanan dan strategi yang terdapat di Kantor Pertanahan Kabupaten Bondowoso;

d) Melakukan kroscek data terhadap pihak-pihak yang terlibat dalam segala proses pelayanan penerbitan sertifikat kepemilikan tanah (melalui wawancara maupun observasi);

e) Menghimpun data yang telah dikumpulkan berdasarkan fokus penelitian; dan

f) Melakukan analisis data, dan penarikan kesimpulan.

Lokasi penelitian dilakukan di Kantor Pertanahan Nasional Kabupaten Bondowoso dengan melibatkan penerima layanan dan pemberi layanan penertbitan sertifikat kepemilikan tanah.

Penelitian ini mempergunakan metode penelitian deksriptif kualitatif dengan melakukan wawancara secara mendalam terhadap para penerima layanan dan pemeberi layanan, observasi partisipan, dan studi dokumentasi.

Adapun teknik pengumpulan data dilakukan melalui observasi partisipan, wawancara mendalam terhadap beberapa penerima layanan dan pemberi layanan pada Kantor Pertanahan Nasional Kabupaten Bondowoso.

\section{Hasil Penelitian dan Pembahasan}

\subsection{Kualitas Pelayanan Penerbitan Sertifikat Kepemilikan Tanah di Kantor Pertanahan Nasional Kabupaten Bondowoso}

Setiap organisasi pelayanan publik mempuyai sistem publik accountability, dimana seluruh warga negara mempunyai hak untuk mengevaluasi kualitas pelayanan yang mereka terima dari berbagai instansi. Dalam menilai kualitas suatu pelayanan memang sangat sulit tanpa mempertimbangkan peran masyarakat sebagai penerima layanan dan aparat pelaksana layanan itu sendiri. Memberi pelayanan kepada masyarakat merupakan salah satu tugas negara atau pemerintah. Seperti halnya dengan Badan Pertanahan Nasional, dimana tugas dan fungsi utama dari lembaga ini adalah memberikan pelayanan pertanahan. Pelayanan yang buruk akan merugikan masyarakat maupun pemerintah itu sendiri.

Menurut Parasuraman et al., (1994) untuk mengetahui kualitas pelayanan yang dirasakan secara nyata oleh konsumen, terdepat beberapa indikator ukuran kepuasan konsumen yang terdapat lima dimensi kualitas pelayanan yaitu tangibles, reability, responsiveness, assurance, dan emphaty.

\subsubsection{Tangible}

Dimensi tangible berhubungan dengan bukti fisik pelayanan, yaitu penampilan petugas/aparatur, kenyamanan tempat, kemudahan dalam proses pelayanan, kedisiplinan petugas/aparatur dalam permohonan pelayanan, kemudahan akses pelanggan dalam permohonan pelayanan, dan penggunaan alat bantu dalam pelayanan. Dengan demikian bukti langsung/ wujud merupakan satu indikator yang paling konkrit. Wujudnya berupa segala fasilitas yang secara nyata dapat terlihat. Dengan demikian bukti langsung/ wujud merupakan satu indikator yang paling konkrit.

Hasil observasi yang dilakukan menunjukkan bahwa para pegawai telah disiplin dalam memberikan pelayanan. Kedisiplinan ini ditunjukkan dari jam kerja yang dilakukan oleh petugas yaitu pukul 08.00-15.00. Elemen tangible (bukti langsung) masih memerlukan adanya perbaikan, dikarenakan pegawai yang kurang disiplin, pelyanan yang masih tergolong sulit dan berbelit- belit, akses yang sulit serta kurangnya alat bantu. Akan tetapi dalam proses pelayanan terhadap masyrakat, pegawai sudah bersikap baik dan ramah, fasilitas yang disediakan telah mendukung proses pelayanan, sehingga masyarakat merasa nyaman.

Dimensi pertama, yaitu dimensi tangible, dimana dimensi ini berhubungan langsung dengan dengan fasilitas layanan dan sumberdaya manusia yang berada di Kantor Pertanhan Nasional Kabupaten Bondowoso. Berdasarkan hasil observasi, dimensi tangible masih memerlukan perbaikan, karena para pegawai masih kurang disiplin, pelayanan yang masih tergolong sulit, akses yang sulit, dan alat bantu yang kurang. Akan tetapi dalam hal pelayanan, para pegawai Kantor Pertanahan Nasional Kabupaten Bondowoso sudah bersikap ramah, 
berpenampilan rapi, dan didukung dengan fasilitas untuk ruang pelyanan juga baik, sehingga masyarakat merasa nyaman dalam menggunakan fasilitas layanan.

Tangible atau bukti langsung merupakan pelyanan yang dirasakan langsung oleh para penerima layanan. Pelayanan yang dirasakan langsung oleh penerima layanan berupa sarana dan prasarana. Dimana para penerima layanan akan selalu merasa nyaman untuk melakukan pelayanan di instansi atau kantor. Dengan memberikan pelayanan yang baik akan memberikan kesan baik bagi para penerima layanan. Salah satu bentuk kualitas pelayanan yang baik adalah menerikan fasilitas yang baik dan nyaman bagi para pengguna layanan.

\subsubsection{Reability}

Dimensi kehandalan merupakan kemampuan untuk melaksanakan jasa yang dijanjikan dengan tepat, akurat, terpercaya, konsisten, dan kesesuaian pelayanan. Untuk mengukur dimensi kehandalan dalam upaya mengetahui kualitas pelayanan publik. Dalam memberikan pelayanan kepada mayarakat baik buruknya pelayanan tersebut dapat dilihat dari kehandalan atau reability dari instansi atau pemberi layanan itu sendiri yang tidak lain dalam konteks ini adalah pemerintah. Untuk mencapai suatu tujuan atau akhir yang baik dalam memberi layanan sangat dibutuhkan sikap tegas dan tanggap dimana itu semua terdapat dalam dimensi reability ini. Menurut Parasuraman (2001) definisi kehandalan atau reability adalah bagi setiap pegawai harus memiliki kemampuan yang handal, mengetahui seluk beluk dari prosedur kerja, mekanisme kerja, memperbaiki berbagai kekurangan yang tidak sesuai dengan prosedur kerja yang diterapkan dan mampu mengarahkan atau menjelaskan proses yang belum dimengerti oleh masyarakat dengan benar dan baik, sehingga pelayanan tersebut diharapkan memberi dampak positif.

Kecermatan petugas dalam proses pelayanan sangat penting bagi pengguna layanan. Apabila petugas tidak cermat dalam melayani pengguna layanan maka akan terjadi kesalahan dan akan menimbulkan pekerjaan baru. Kantor Pertanahan Nasional Kabupaten Bondowoso memiliki standar pelayanan yang telah diatur dalam peraturan Kepala Badan Pertanahan Nasional Republik Indonesia No. 1 Tahun 2010 tentang standar pelayanan dan pengaturan pertanahan. Berdasarkan peraturan yang telah ditetapkan tersebut pelayanan sertifikat kepemilikan tanah dapat diselesaikan dalam jangka waktu 98 hari akan tetapi pada kenyataannya dilapangan penerbitan sertifikat kepemilikan tanah melebihi batas yang telah ditentukan.

Dimensi reability atau kehandalan yang merupakan kemampuan yang bisa memberikan layanan secara tepat, akurat, tidak terlalu banyak melakukan kesalahan dan menyelesaikan pelayanan sesuai dengan standar yang telah diterapkan. Hasil penelitan yang dilakukan oleh peneliti di Kantor Pertanahan Nasional Kabupaten
Bondowoso dalam hal kehandalan memberikan pelayanan masih perlu adanya peningkatan terutama dalam masalah keakuratan, kecermatan, ketelitian, dan masalah waktu.

\subsubsection{Assurance}

Suatu organisasi sangat membutuhkan adanya kepercayaan memberikan pelayanan kepada orang-orang yang dilayaninya. Untuk memperoleh suatu pelayanan yang meyakinkan, maka setiap pegawai berupaya untuk menunjukkan kualitas layanan yang meyakinkan sesuai dengan bentuk-bentuk pelayanan yang memuaskan yang diberikan, bentuk-bentuk pelayanan yang sesuai dengan komitmen organisasi yang ditunjukkan dan memberikan kepastian pelayanan sesuai dengan perilaku yang ditunjukkan. Assurance itu sendiri meliputi indikatorindikator yang telah diatur diantaranya, yaitu petugas memberikan tepat waktu dalam pelyanan, petugas memberikan jaminan biaya dalam pelayanan, dan petugas memberikan legalitas dalam pelayanan.

Sertifikat kepemilikan tanah itu sendiri merupakan dokumen yang mempunyai legalitas yang sangat tinggi dan mempunyai jaminan kepastian hukum yang jelas. Tidak hanya mempunyai kepastian hukam, sertifikat kepemilikan tanah ini dapat dijadikan sebagai jaminan dalam menjalani hal ekonomi untuk masyarakat. Hal ini juga yang banyak menjadi alasan kenapa masyarakat banyak melakukan pelegalan atas tanahnya. Belum dianggarkan secara penuh, sehingga menjadi penghambat dalam pelaksanaan agenda kegiatan. Berdasarkan observasi yang dilakukan, masih terdapat permasalahan terhadap sertifikat kepemilikan tanah yang diterbitkan oleh Kantor Pertanahan Nasional Kabupaten Bondowoso. Hal ini terlihat dari adanya sertifikat tanah yang bermasalah dan tidak bisa digunakan sebagai jaminan, sehingga pemilik sertifikat harus mengurus kejelasan dari sertifikat miliknya. Selain itu banyaknya sengketa tanah yang masuk ke Kantor Pertanahan Nasional Kabupaten Bondowoso.

\subsubsection{Responsiveness}

Responsiveness atau daya tanggap merupakan tuntutan pelayanan yang menyikapi berbagai keluhan dari bentuk-bentuk pelayanan yang diberikan menjadi suatu respek positif dari daya tanggap pemberi pelayanan dan yang menerima layanan. Respon pegawai terhadap kesulitan masyarakat masih kurang baik. Dapat disimpulkan daya tanggap pegawai Kantor Pertanahan Kabupaten Bondowoso sudah baik, akan tetapi terdapat beberapa yang masih kurang karena pelayanan kurang cepat dan belum adanya ketepatan waktu, respon terhadap kesulitan pengguna layanan juga masih kurang.

Semua para pengguna layanan yang datang ke Kantor Pertanahan Nasional Kabupaten Bondowoso sudah direspon dengan baik oleh pegawai yang sedang 
bertugas. Akan tetapi, pelayanan yang diberikan oleh para pemberi layanan kurang cepat dan belum adanya ketepatan waktu dalam penyelesaian penerbitan sertifikat kepemilikan tanah dan juga respon terhadap kesulitan pengguna layanan juga masih kurang dan perlu adanya peningkatan kualitas. Akan tetapi, pelayanan yang diberikan oleh para pemberi layanan kurang cepat dan belum adanya ketepatan waktu dalam penyelesaian penerbitan sertifikat kepemilikan tanah dan juga respon terhadap kesulitan pengguna layanaa juga masih kurang dan perlu adanya peningkatan kualitas.

Jika pelayanan responsiveness dijalankan dengan baik, penjelasan yang bijaksanan, penjelasan yang mendetail, penjelasan yang membina, penjelasan yang mengarahkan dan penjelasan yang baik; akan memberikan dampak posotif pada kualitas pelayanan itu sendiri atau bisa dikatakan pada dimensi responsiveness telah berhasil dijalankan. Dan itu menjadi satu bentuk keberhasilan atau prestasi dalam bekerja.

\subsubsection{Emphaty}

Empati dalam suatu pelayanan adalah adanya suatu perhatian, keseriusan, simpatik, pengertian, dan keterlibatan pihak-pihak yang berkepentingan dengan pelayanan untuk mengembangkan dan melakukan aktivitas pelayanan sesuai dengan tingkat pengertian dan pemahaman dari masing masing pihak tersebut sekaligus untuk meningkatkan kinerja dari suatu organisasi publik. Elemen emphaty meliputi indikator, mendahulukan kepentingan pemohon, petugas melayani dengan sikap ramah dan sopan santun, petugas tidak diskriminatif (membeda-bedakan) terhadap pengguna layanan, dan petugas melayani dan menghargai setiap para pengguna layanan. Dimensi emphaty di Kantor Pertanahan Nasional Kabupaten Bondwoso sudah baik, dan perlu tingkatkan lagi agar selalu baik.

Zoeldhan (2012) menyatakan bahwa empati dalam suatu pelayanan publik merupakan adanya suatu perhatian, keseriusan, simpatik, pengertian dan keterlibatan pihak-pihak yang berkepentingan dalam pelayanan untuk mengembangkan dan melakukan aktivitas pelayanan sesuai dengan pengertian dan pemahaman dari masing-masing pihak. Dimensi empati membutuhkan adanya saling mengerti satu sama lain antara pemberi layanan dan penerima layanan agar tercipta suatu hubungan yang balance atau selaras.

Dwiyanto (2008, p. 141) yang menyatakan bahwa keberhasilan organisasi-organisasi yang bergerak dibidang pelayanan ditentukan oleh segitiga pelayanan (the service triangle) dimana pelayanan disusun atas strategi pelayanan yang baik, orang digaris depan yang berorientasi pada pelanggan/ konsumen, serta sistem pelayanan yang ramah dan baik. Untuk itulah selain memperbaiki kualitas dan kinerja sumber daya manusia dibutuhkan pula strategi yang sesuai dengan kondisi lingkungan, sehingga kualitas pelayanan dapat ditingkatkan.

\section{Kesimpulan}

Berdasarkan uraian hasil penelitian tentang dimensi pelayanan tersebut, kualitas pelayanan sertifikat kepemilikan tanah di Kantor Pertanahan Nasional Kabupaten Bondowoso masih perlu ditingkatkan. Beberapa beberapa indikator dalam elemen kualitas pelayanan masih belum terpenuhi secara maksimal. Permasalahan yang paling utama, yaitu masalah waktu, belum adanya kepastian waktu dalam penyelesain sertifikat kepemilikan tanah, waktu yang dibutuhkan untuk penyelesain sertifikat tidak sesuai dengan SOP yang telah ditetapkan. Selain itu, pegawai masih kurang disiplin dan kurang cermat dalam melakukan proses pelayanan. Kemudian masih terdapat diskriminasi terhadapa pengguna layanan untuk penerbitan sertifikat kepemilikan tanah dimana yang menggunakan calo lebih cepat dibandingkan mengurus langsung ke kantor sendiri. Pengurusan sertifikat kepemilikan tanah yang dilakukan sendiri lebih sulit karena berbelit-belit, dan harus berkalikali datang ke kantor Pertanahan untuk melihat apakah sertifikat sudah jadi atau belum.

Kualitas pelayanan penerbitan sertifikat kepemilikan tanah di Kantor Pertanahan Kabupaten Bondowoso masih perlu untuk ditingkatkan lagi. Beberapa indikator yang tertera dalam elemen kualitas pelyanan masih belum terpenuhi secara maksimal. Permasalahan yang paling utama di Kantor Pertanahan Nasional Kabupaten Bondowoso adalah ketiadaan kepastian waktu dalam penyelesaian sertifikat tanah. Waktu penyelesaian tidak sesuai dengan SOP yang telah diatur oleh Kantor Pertanahan Kabupaten Bondowoso. Pegawai Kantor Pertanahan Nasional Kabupaten Bondowoso kurang disiplin dan kurang cermat.

\section{Daftar Pustaka}

Abdul Wahab, Solihin. (2012). Analisis Kebijakan Dari Formulasi ke Penyusunan Model-model Implementasi Kebijakan Publik. Jakarta: Bumi Aksara.

Miller, Alex., \& Dess, Gregory G. (1993). Strategic Management (International Edition). New York: Mc Grow Hill.

Dwiyanto, Agus. (2005). Mewujudkan Good Governance Melalui Pelayanan Publik. Yogyakarta: Pustaka Pelajar.

Dwiyanto, Agus. (2008). Mewujudkan Good Governance Melalui Pelayanan Publik. Yogyakarta: Gadjah Mada University Press. 
Dwiyanto, Agus. (2010). Manajemen Pelayanan Publik (Peduli, Inklusi dan Kolaboratif). Yogyakarta: Gadjah Mada University Press.

Lynch, Richard. (2006). Corporate Strategy. England: Prentice Hall.

Parasuraman, A., Berry, Leonard L., \& Zeithaml, Valarie A. (1994). Reassessment of Expectations as a Comparison Standar in Measurung Service Quality: Implications for Future Research. Journal of Marketing, 58 (Januari), 111-124.

Parasuraman, A. Valerie. (2001). Delivering Quality Service. (Sutanto, Penerjemah). New York: The Free Press.

Sinambela, Lijan Poltak. (2014). Reformasi Pelayanan Publik. Jakarta: Bumi Aksara.

Sutedi, Adrian. (2012). Sertifikat Hak Atas Tanah. Jakarta: Sinar Grafika.

Tjiptono, Fandy. (1997). Prinsip-pronsip Total Quality Service (TQS). Yogyakarta: Andi

Zoeldhan. (2012). Pengertian Pelayanan. Jakarta: Gramedia. 